\title{
4. UPPER OLIGOCENE TO PLEISTOCENE OSTRACODA FROM GUYOTS IN THE WESTERN PACIFIC: HOLES 871A, 872C, AND 873B ${ }^{1}$
}

\author{
Robin Whatley ${ }^{2}$ and Ian Boomer ${ }^{2}$
}

\begin{abstract}
Assemblages of upper Oligocene to Pleistocene Ostracoda are described from pelagic sediments capping three guyots in the western Pacific Ocean. Recent studies have shown that a high percentage of seamount Ostracoda are restricted (i.e., endemic) to these bathymetrically isolated sites. In the following we detail changes in the Ostracoda (diversity, abundance, dominance, endemism, faunal turnover) from upper Oligocene to Pleistocene sediments encountered during Ocean Drilling Program Leg 144. Our results support previous observations on guyots and indicate that their high levels of endemism do not simply reflect a poor knowledge of the fauna in that region but truly reflect their bathymetrical isolation. Furthermore, whatever global event or events affected the deep-sea Ostracoda during the Miocene, the guyot faunas were not isolated from these changes.
\end{abstract}

\section{INTRODUCTION}

As our knowledge of deep-sea Ostracoda has advanced, it has become apparent that there exists in modern to Tertiary oceans both a widespread pandemic element and regional, more endemic taxa (Whatley and Ayress, 1988; Coles et al., 1990). Furthermore, patterns of migration and centers of evolutionary radiation have been identified (Whatley et al., 1984, 1986; Whatley, 1987).

Marine podocopid Ostracoda are, to a large extent, bathymetrically controlled in their distribution (although not directly so), and assemblages of particular Ostracoda have been associated with different water masses (Dingle et al., 1990). Podocopid Ostracoda lack a pelagic larval stage; therefore, their migration is determined by individual locomotory capabilities (active element) and by the nature of prevailing bottom currents (passive element). Their carbonate carapaces effectively exclude them from depths below the CCD (at about $4800 \mathrm{~m}$ below sea level [mbsl] in the Pacific Ocean) and, in general, their migration must take place along routes above this level. Chance migration events, in some cases against existing current directions when transported by other organisms, cannot be ruled out but such occurrences are not considered to be significant. Ostracoda living on the summits of guyots are denied the benefits of floating weed, wood, or birds as mechanisms that assist the migration of shallow-water species (Teeter, 1973; Titterton and Whatley, 1988). The origin of these guyot assemblages and their subsequent evolution may provide an insight into regional paleoceanographical changes.

The Ostracoda that inhabit guyot summits may be divided into two groups. First are those that have evolved there and that are found only on that guyot. These are considered to be the endemic taxa. The second group comprises those species that either migrated onto the summit, having evolved elsewhere, or evolved (originated) on the guyot, but having subsequently migrated, can be found both on the guyot and adjacent parts of the seafloor or adjacent guyots. These taxa are considered nonendemic.

It has been established that deep-sea benthic assemblages of Ostracoda from guyot sites exhibit high levels of endemism compared to the highly pandemic non-guyot, deep-sea assemblages typically at 1000-2000 mbsl (Larwood and Whatley, 1993; Boomer and Whatley, in press). Larwood and Whatley (1993) noted that endemism values

\footnotetext{
'Haggerty, J.A., Premoli Silva, I., Rack. F., and McNutt, M.K. (Eds.), 1995. Proc. ODP, Sci. Results, 144: College Station, TX (Ocean Drilling Program).

${ }^{2}$ Institute of Earth Studies, University of Wales, Aberystwyth, Dyfed, SY23 3DB, United Kingdom.
}

for the Pliocene-Pleistocene interval of a number of non-guyot, $\mathrm{Pa}$ cific deep-sea sites range from $5 \%$ to $25 \%$, compared with a range from $50 \%$ to $60 \%$ for the Horizon (DSDP Sites 200/202) and Ita Mai Tai (DSDP Sites 44 and 171) guyots during the same interval.

The bathymetric isolation of the guyot summits has resulted in increased rates of evolutionary turnover with only limited exchange between these faunas and the surrounding bathyal and abyssal plains.

Endemic species are those known only from one site; they have not been recorded from other guyots or from the surrounding abyssal plains. The level of endemism in a sample is calculated as the percentage of recorded and Lazarus species (i.e., those temporarily absent from a given sample) known only from that site. These values must, inevitably, reflect the extent of our knowledge of deep-sea Ostracoda in the study area. The fewer sites that are available for study, the greater will be the likelihood that some of the recorded taxa will appear to be endemic. This is particularly true in this study and must be considered when interpreting our results. As more Pacific guyots are studied, it has become apparent that endemism levels will be higher than those of non-guyot, deep-sea assemblages in the region. Because the submarine summits of these guyots are commonly at a water depth of about $1000-1500 \mathrm{mbsl}$, it is perhaps surprising that endemism levels are not higher than observed. We can demonstrate that migration onto the guyots, by whatever means, does occur despite the bathymetric isolation of these sites.

That some pandemic species are recorded from the guyot sequences attests to some faunal exchange between the guyot summit and the surrounding seafloor. The level of endemism in the guyot assemblages and the rate of migration onto the guyot may reflect changes in the local water-mass structure and, to a certain extent, the drowning history of the guyot. Such changes will affect the accessibility of the guyot to the migration and immigration of benthic organisms.

A number of recent unpublished studies have identified distinct endemic elements in the Tertiary-Quaternary Ostracoda assemblages recovered from Indo-Pacific guyot sites (Downing, 1985; Ayress, 1988; J.G. Larwood, unpubl. data, 1992). Further studies in the IndoPacific region have also provided comparative data from non-guyot sites (Ainsworth, 1982; Smith, 1983; Dainty, 1984; Millson, 1987). These works have been summarized by Larwood and Whatley (1993).

\section{Tertiary Evolution of Ostracoda on Pacific Guyots}

Previous studies from Ita Mai Tai (Downing, 1985; Ayress, 1988; J.G. Larwood, unpubl. data, 1992) and Horizon (J.G. Larwood, unpubl. data, 1992) guyots in the Mid-Pacific Mountains and a number of guyots in the Emperor Seamount Chain (Larwood and Whatley, 
A

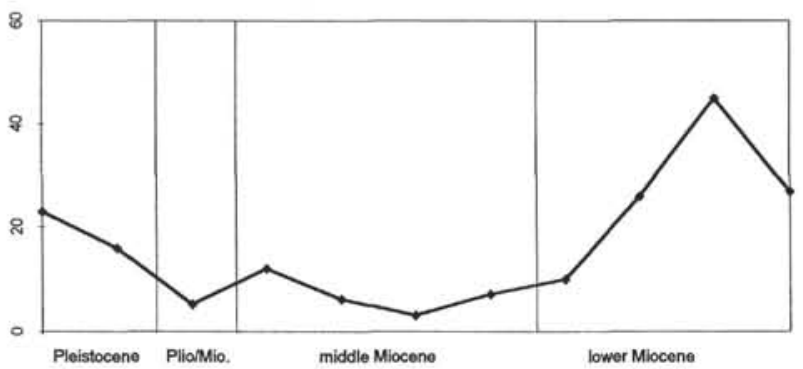

B

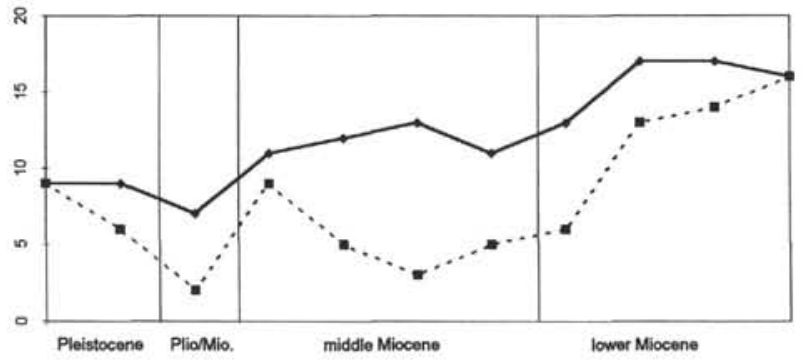

c

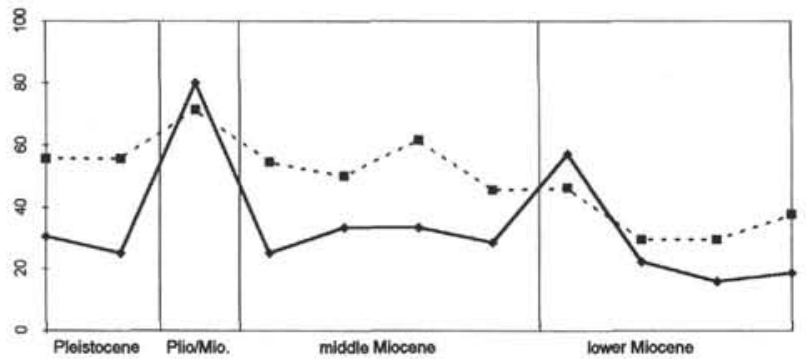

D

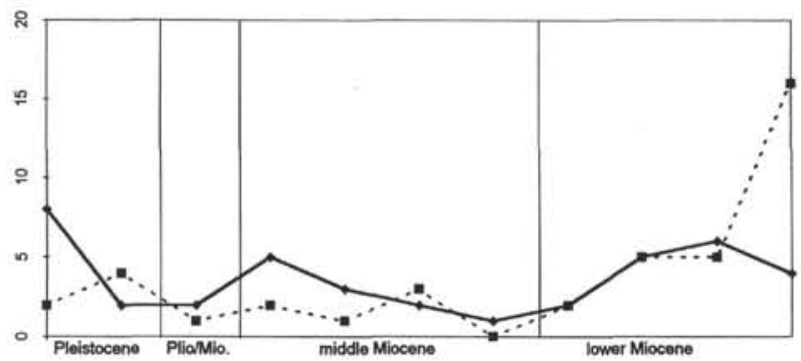

Figure 1. Faunal analysis of the Ostracoda from Hole 871A. A. Number of specimens (Ostracoda abundance) per sample. B. Simple-species diversity: recorded number of species (broken line), and recorded number of species + Lazarus taxa (solid line). C. Percentage composed of the most dominant species (solid line), and percentage of endemic species per sample (broken line). D. Faunal turnover: number of extinctions (solid line) per sample, and number of originations or first appearances (broken line) per sample. Data points refer to samples listed in Table 1 (not to scale).

1993; J.G. Larwood, unpubl. data, 1992.) indicate that, in some cases, the Late Cretaceous shallow-water Ostracoda of these sites initially adapted to the subsequent deepening phase. The subsidence of the guyot summits eventually stabilized, and pelagic sediments began to accumulate during the Tertiary.

The inception of the psychrosphere, caused by the intensification of the thermocline at approximately $40 \mathrm{Ma}$, initiated a temperature barrier that denied access between the upper thermospheric and the lower psychrospheric layers of the world ocean for many organisms. The absence of such a barrier during the Late Cretaceous and the early Paleogene allowed otherwise thermophylic taxa to adapt, albeit slowly, to the cold, deeper water conditions as the guyots on which they lived slowly subsided. One taxon to achieve this was the genus Cytherelloidea, generally noted for its preference for warm-water conditions, as witnessed on Horizon (Larwood and Whatley, 1993) and Allison (ODP Site 865, Boomer and Whatley, in press) guyots. In general, however, the shallow-water assemblages were replaced by typical deep-sea faunas (e.g., on Suiko Guyot, DSDP Site 433, Emperor Seamount Chain), although no Ostracoda are recorded after the disappearance of the shallow-water taxa in some cases (e.g., Ojin [DSDP Site 430] and Koko [DSDP Site 308] guyots, both in the Emperor Seamount Chain; J.G. Larwood, unpubl. data, 1992).

In this study, we have analyzed the mainly Neogene Ostracoda recovered from the pelagic cap of three guyots in the Marshall Islands, western Pacific. The summits are capped by foraminifernannofossil oozes; most samples yielded Ostracoda.

\section{METHODS}

In all, 11 samples $\left(50 \mathrm{~cm}^{3}\right.$ each) were investigated from Hole $871 \mathrm{~A}, 28$ from Hole 872C, and a further 30 samples from Hole 873B. All samples were washed over a $200-\mu \mathrm{m}$ mesh sieve to remove the mud fraction and then air-dried; they were then dry sieved through $60-$ and $100-\mu \mathrm{m}$ mesh sieves. The largest two fractions were completely picked (i.e., all Ostracoda $>125 \mu \mathrm{m}$ ) under a binocular microscope and arranged in faunal slides. The number of left and right valves of each species in a sample was recorded, and the greater number, added to the number of articulated carapaces, was taken as an estimate of the minimum number of individuals present in that sample. It is these values that are given in the distribution range charts (Tables 1-3). Figured specimens were coated with gold and photographed under the Cambridge 140 SEM at Aberystwyth. All figured specimens and faunal slides are held in the collections of the Micropaleontology Museum, University of Wales, Aberystwyth (UWA).

Simple species diversity (i.e., number of species) for the Ostracoda has been calculated in two ways: (1) as the number of species recorded in a given sample (i.e., the recorded diversity), and (2) as the recorded diversity plus those "Lazarus Taxa" known to occur stratigraphically above and below the current sample but temporarily absent from the assemblage, possibly as a result of sample inadequacy. Reworking of specimens can lead to increases in such Lazarus occurrences. No instances of reworking were identified in the present study; this is partly because of our incomplete knowledge of the spatial and stratigraphic distribution of Ostracoda in this region. Long periods of absence from the stratigraphic record need not necessarily indicate reworking, given the often low abundance of specimens in deep-sea sediments. Both values are plotted on the simple speciesdiversity graphs (Figs. 1B, 2B, and 3B). In the following discussions of diversity, we consider only the Recorded + Lazarus Taxa calculation because we think that this provides a more accurate assessment of biological diversity for the interval.

\section{Site 871}

Hole 871A (Limalok or "Harrie" Guyot, $5^{\circ} 33.4^{\prime} \mathrm{N}, 172^{\circ} 20.7^{\prime} \mathrm{E}$ ) penetrated up to $140 \mathrm{~m}$ of pelagic sediments. Two units are recognized: an upper Miocene to Pleistocene light grey nannofossil-foraminifer ooze was separated from a lower to mid-Miocene foraminiferal ooze by a late mid- to latest Miocene hiatus. The pelagic cap rests on manganese-capped Paleogene, shallow-water wackestones and grainstones (Premoli Silva, Haggerty, Rack, et al., 1993, pp. 41-103). We examined 11 samples from the Miocene to Pleistocene interval; the biostratigraphic distribution of Ostracoda that we determined is given in Table 1 . The assemblages are primarily composed of various cytherurid taxa together with species of Krithe, Eucythere, Tongacythere, and Bradleya.

The two youngest samples yielded specimens of shallower water marine (Cluthia? sp.) and freshwater (Limnocythere? sp.) origin. 
A

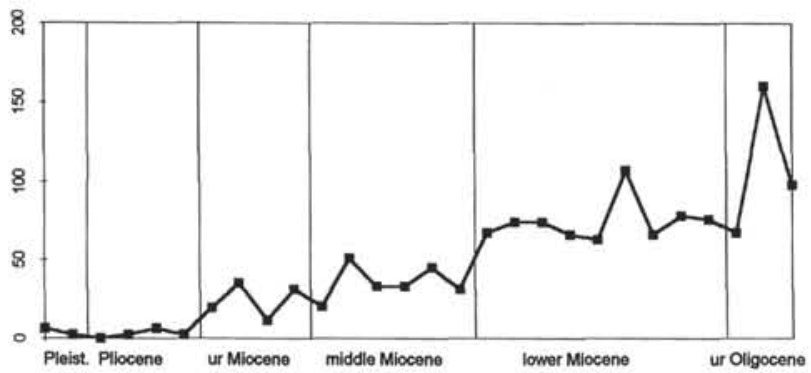

B

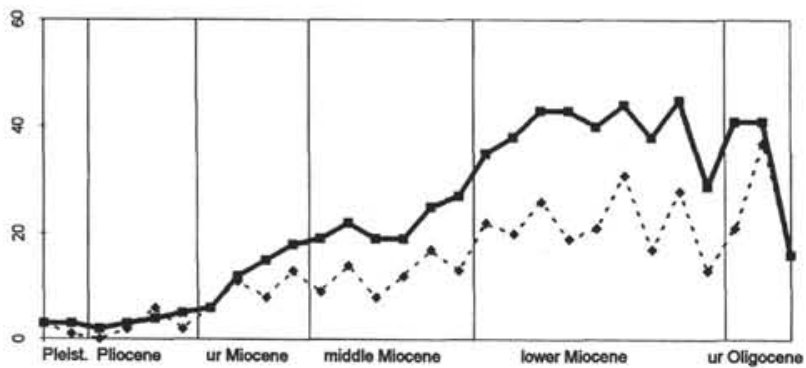

C

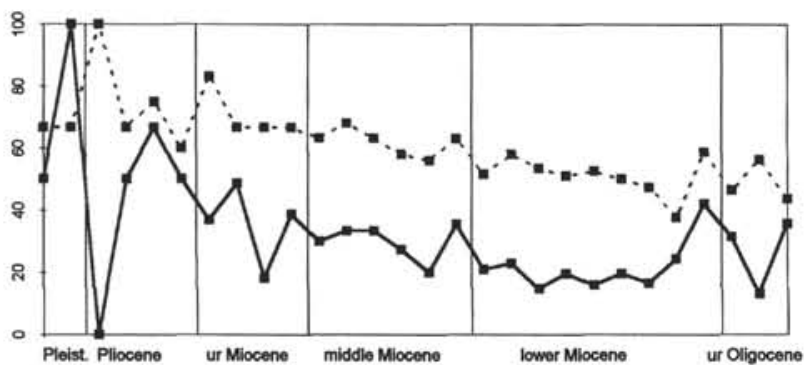

D

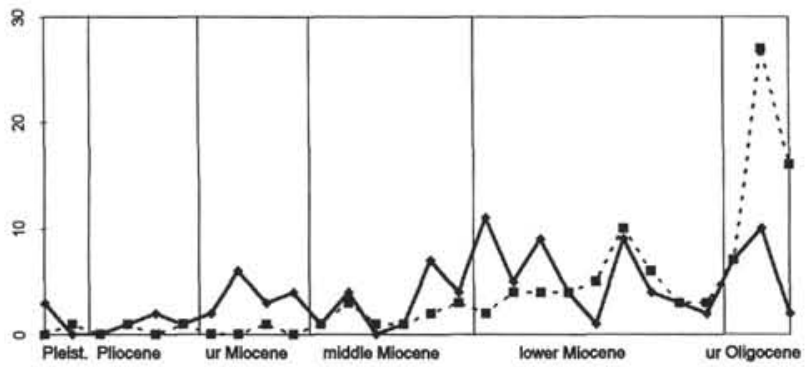

Figure 2. Faunal analysis of the Ostracoda from Hole 872C. A. Number of specimens (Ostracoda abundance) per sample. B. Simple-species diversity: recorded number of species (broken line), and recorded number of species + Lazarus taxa (solid line). C. Percentage composed of the most dominant species (solid line), and percentage of endemic species per sample (broken line). D. Faunal turnover: number of extinctions (solid line) per sample, and originations or first appearances (broken line) per sample. Data points refer to samples listed in Table 2 (not to scale). ur = upper.

These were presumably transported by surface-water currents from surrounding islands; they are marked by an asterisk on the accompanying range chart (Table 1).

The assemblages recovered are of low abundance $(<46$ specimens per sample; Fig. 1A) and low diversity ( $<18$ species per sample; Fig. 1B), which makes interpretation of the diversity, dominance, and endemism data very tentative. Almost half of the species recorded are endemic to the site. Indeed, the percentage of endemic species (Fig. 1C) increases (from about $40 \%$ to $60 \%$ ) throughout the sequence whereas diversity (Fig. 1B) falls gradually (from 16 to 9 species). Low specimen abundance may be explained by the winnowing action
A
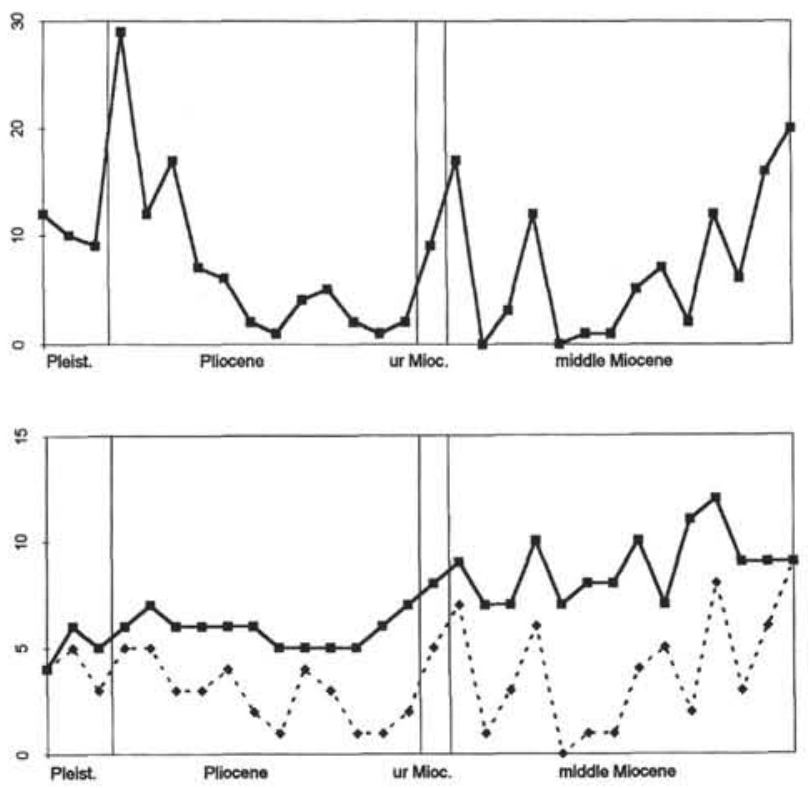

C

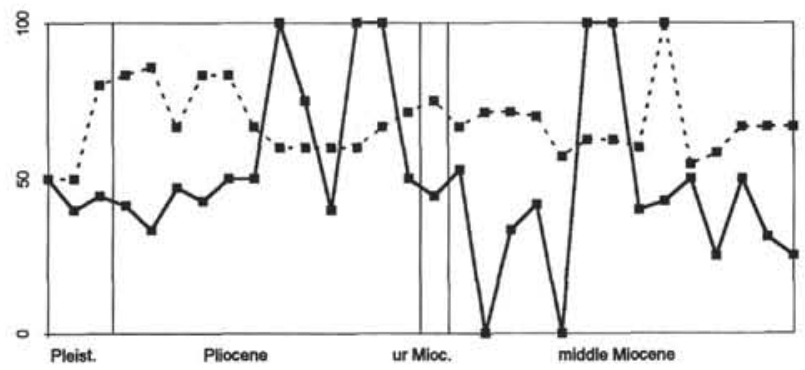

D

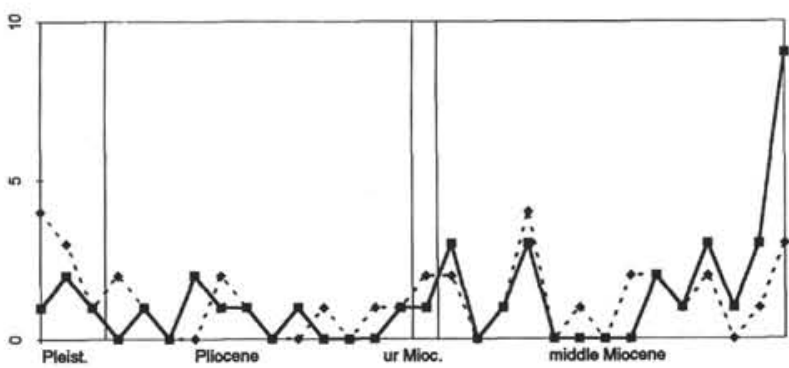

Figure 3. Faunal analysis of the Ostracoda from Hole 873B. A. Number of specimens (Ostracoda abundance) per sample. B. Simple-species diversity: recorded number of species (broken line), and recorded number of species + Lazarus taxa (solid line). C. Percentage composed of the most dominant species (solid line), and percentage of endemic species per sample (broken line). D. Faunal turnover: number of extinctions (solid line) per sample, and originations or first appearances (broken line) per sample. Data points refer to samples listed in Table 3 (not to scale). ur $=$ upper.

of submarine currents. The absence of many small juvenile stages in the samples containing larger adults implies the removal of finegrained material. Alternatively, the gradual decrease in specimen abundance may reflect an increase in the sedimentation rate effectively "diluting" the Ostracoda. The paucity of the material precludes further interpretation.

\section{Site 872}

Hole $872 \mathrm{C}$ (Lo-En Guyot, $\left.10^{\circ} 5.8^{\prime} \mathrm{N}, 162^{\circ} 51.9^{\prime} \mathrm{E}\right)$ penetrated 140 $\mathrm{m}$ of late Oligocene to Pleistocene pelagic sediments (Premoli Silva, 
Table 1. Ostracod biostratigraphy of Hole 871A.

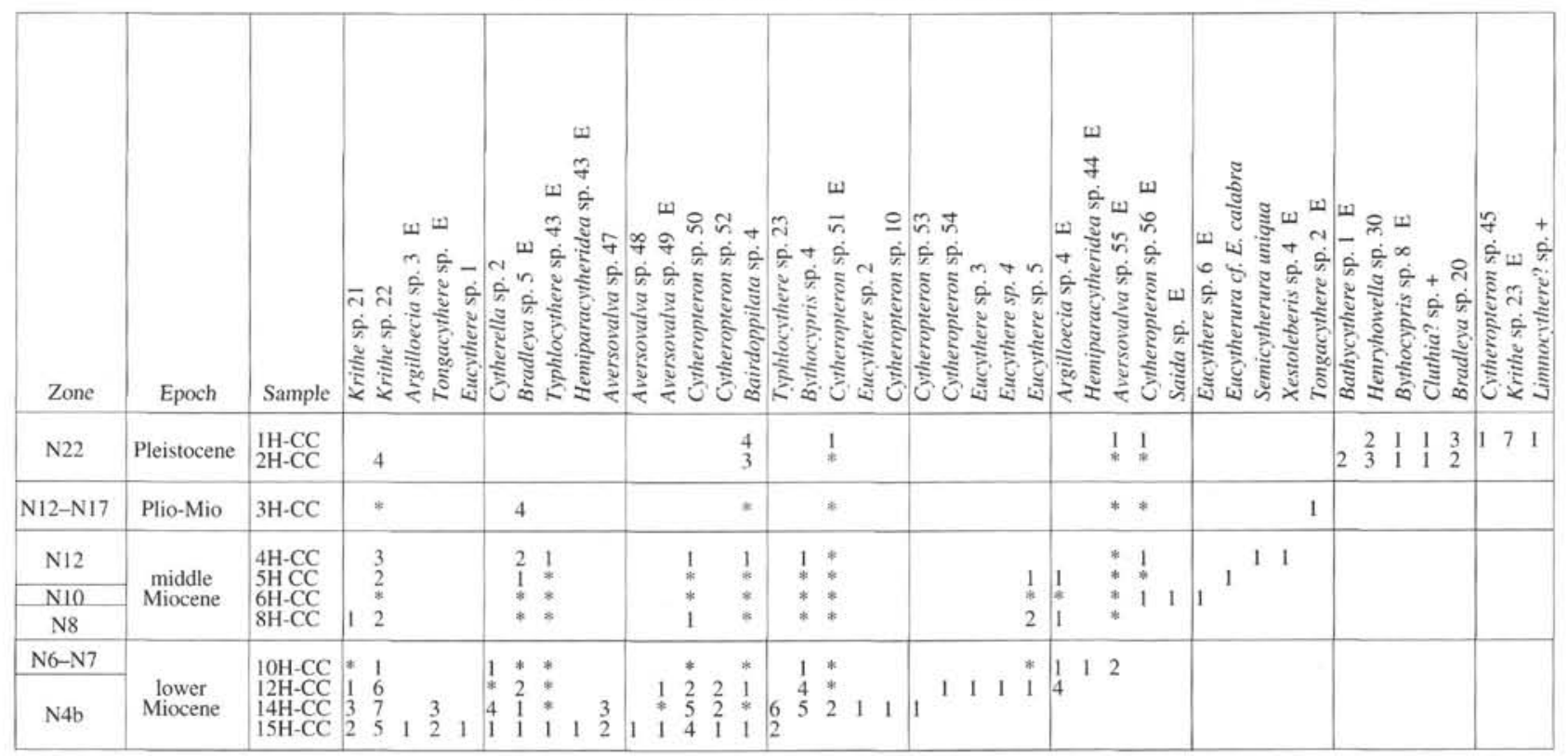

Notes: Foraminifer zones and stratigraphic distribution after Shipboard Scientific Party $(1993 \mathrm{a})$. Asterisk $(*)=$ Lazarus occurrence. $\mathrm{E}=$ taxa considered to be endemic to each site. Plus $\operatorname{sign}(+)=$ allochthonous species.

Haggerty, Rack, et al., 1993, pp. 105-144). The sediments comprised an upper unit of late Miocene to Pleistocene, white to very pale brown, nannofossil foraminifer ooze intercalated with foraminifer ooze. The lower unit comprised very pale brown, homogeneous, foraminifer ooze with a well-sorted, winnowed sand texture of late Oligocene to late Miocene age. The two units were separated by a late middle to early late Miocene transitional layer containing mixed floras and faunas followed by a disconformity.

The pelagic sediments yielded moderate- to low-abundance assemblages $(<160$ specimens per sample, decreasing gradually throughout the sequence; Fig. 2A) more diverse than those at Site $871(<46$ species per sample; Fig. 2B). As at Site 871 , the Miocene to Pleistocene interval is marked by a pattern of decreasing diversity (and also abundance) while the dominance and endemism levels increase.

Specimen abundance in the upper Oligocene and lower Miocene interval is between 60 and 160 individuals with suites of juvenile instars present, indicating in situ assemblages not subject to winnowing. The middle Miocene to Pleistocene sequence records a steady decrease in abundance to less than 10 individuals per sample. The very low abundance in the upper Miocene to Pleistocene interval renders any analysis of these assemblages very tentative. The decrease in abundance throughout the sequence is echoed by a concomitant decrease in diversity (Fig. 2B). Conversely, the dominance and endemism levels (Fig. 2C) increase throughout most of the sequence.

There is a distinct change in the abundance, diversity, dominance, and faunal turnover (number of extinctions and originations; Fig. 2D) at about the lower/middle Miocene boundary. Before this time, the three former parameters had all been relatively stable (ignoring extreme values). Subsequently, abundance and diversity begin to decline while dominance increases. Across the lower/middle Miocene boundary, the rate of species origination decreases to almost zero for the rest of the sequence, whereas extinction rates are consistently high.

Almost one third of the 106 species identified were only recorded in one sample. As with the Hole 871A samples, the assemblages are dominated by cytherurid species belonging to the genera Aversovalva, Cytheropteron, Eucytherura, and Hemiparacytheridea, as well as species of Eucythere, Krithe, Tongacythere, and Bradleya. The Site 872 assemblages can be distinguished by the presence of Cytheralison sp. 1 throughout the Oligocene to Miocene interval, with one further record in the Pliocene. This bythocytherid species constitutes between $5 \%$ and $25 \%$ of the fauna for much of the Oligocene and Miocene. A complete biostratigraphy is given in Table 2.

\section{Site 873}

Hole 873B (Wodejebato or "Sylvania Guyot", $11^{\circ} 53.8^{\prime} \mathrm{N}$, $164^{\circ} 55.2^{\prime} \mathrm{E}$ ) cored $54 \mathrm{~m}$ of lower Miocene to Pleistocene pelagic sediments resting on a manganese-topped limestone sequence of Late Cretaceous age (Premoli Silva, Haggerty, Rack, et al., 1993, pp. 145-207). An upper unit of light grey nannofossil foraminifer ooze of latest Miocene to Pleistocene age overlies a lower, pale brown, mainly homogeneous foraminifer ooze with a well-sorted, winnowed, medium sand texture of middle to early Miocene age. The two units are separated by a late middle to late Miocene disconformity.

Ostracod recovery was similar to that from Site 871 , characterized by low-abundance and low-diversity assemblages. Fewer than 10 specimens were recovered in the majority of samples (Fig. 3A). Diversity decreases through the Miocene to Pleistocene (Fig. 3B), echoing the pattern witnessed at Sites 871 and 872 . Dominance and endemism remain relatively constant throughout the sequence (Fig. 3C). Two thirds of the species recorded are considered to be endemic to this site. Figure 3D indicates a relatively constant rate of faunal turnover, with 1-2 originations and 1-2 extinctions per sample.

The assemblages are similar to those of the two previously discussed sites; again, they are dominated by cytherurid taxa, as well as Krithe and Bradleya species. Cytheralison sp. 1 is also recorded at Site 873 , but only a few specimens were present (in the middle Miocene). A detailed biostratigraphy is given in Table 3. As with the Site 871 assemblages, the present material is too sparse to infer faunal trends with any degree of confidence; therefore, no further analysis is made.

\section{SUMMARY}

Almost 200 different species of Ostracoda were recovered from 69 samples taken from three, mainly Neogene, guyot cores in the western Pacific. More than half the taxa identified are considered to be endemic to the individual sites. This is much higher than would be expected from three similarly equidistant cores taken from bathyal 
nonguyot sites at the same depths (based on data from Dainty, 1984; Downing, 1985; Millson, 1987; Ayress, 1988). High endemism figures support previous observations that guyot assemblages truly reflect their bathymetric isolation.

The percentage of common species between each site in the present study is low. Communality between Holes $871 \mathrm{~A}$ and $872 \mathrm{C}$ is $14 \%$, between Holes $872 \mathrm{C}$ and $873 \mathrm{~B}$ it is $8.5 \%$, and between Holes $871 \mathrm{~A}$ and $873 \mathrm{~B}$ it is $7.5 \%$. The Ostracoda recovered from the pelagic sediments are all indicative of upper to middle bathyal depths, and there is no evidence of increasing palaeodepth through time.

Despite the poor recovery of Ostracoda in some intervals, all three cores display a pattern of decreasing simple-species diversity through the Miocene and Pliocene. Similar diversity decreases have been recorded from deep-sea assemblages of Ostracoda from Horizon Guyot (DSDP Sites 171 and 44) and less markedly so from Ita Mai Tai Guyot (DSDP Site 200) (Larwood and Whatley, 1993). Further evidence indicating the global nature of this Miocene event and its effect on the deep-sea Ostracoda is given in Benson et al. (1984, 1985). It would appear, therefore, that whatever global event or events affected the deep-sea Ostracoda during the Miocene, the guyot faunas were not isolated from these changes. An Atlantic-wide foraminifer/paleoceanographic event has also been identified recently.

The marked faunal decline witnessed at Hole $872 \mathrm{C}$ may have been initiated by external environmental parameters, occurring around the lower/middle Miocene boundary.

\section{ACKNOWLEDGMENTS}

The authors wish to acknowledge the tenure of a Natural Environment Research Council ODP grant during the course of this research. Mr. Richard Jones of UWA is thanked for tireless assistance with selecting and photographing many of these samples. Mr. D. Griffiths of UWA is acknowledged for his photographic skills.

\section{REFERENCES}

Ainsworth, N.R., 1982. The biostratigraphy and palaeoecology of the Miocene and Pliocene Ostracoda of the Northern Indian Ocean [M.S. thesis]. University College, Wales.

Ayress, M., 1988. Late Pliocene to Quaternary deep-sea Ostracoda from the Eastern Indian and Southwestern Pacific Oceans [Ph.D. dissert.]. University College, Wales.

Benson, R.H., Chapman, R.E., and Deck, L.T., 1984. Paleoceanographic events and deep-sea ostracodes. Science, 224:1334-1336.

, 1985. Evidence from the Ostracoda of major events in the South Atlantic and world-wide over the past 80 million years. In Hsü, K.J., and Weissert, H. (Eds.), South Atlantic Paleoceanography: Cambridge (Cambridge Univ. Press), 325-350.

Boomer, I.D., and Whatley, R.C., in press. Cainozoic Ostracoda from guyots in the Western Pacific: Leg 143, Holes 865B and 866B. In Winterer, E.L.,
Sager, W.W., Firth, J.V., and Sinton, J.M. (Eds.), Proc. ODP, Sci. Results, 143: College Station, TX (Ocean Drilling Program).

Coles, G., Ayress, M., and Whatley, R.C., 1990. Acomparison of North Atlantic and Pacific Cainozoic deep-sea Ostracoda. In Whatley, R.C., and Maybury, C. (Eds.), Ostracoda and Global Events: London (Chapman and Hall), 287-306.

Dainty, E.J., 1984. Pleistocene Ostracoda from four DSDP Sites of the SouthWest Pacific [M.S. thesis]. University College, Wales.

Dingle, R.V., Lord, A.R., and Boomer, I.D., 1990. Deep-water Quaternary Ostracoda from the continental margin off south-western Africa (SE Atlantic Ocean). Ann. S. Afr. Mus., 99:245-366.

Downing, S.E., 1985. The taxonomy, palaeoecology, biostratigraphy and evolution of Pliocene Ostracoda from the W. Pacific [Ph.D. dissert.]. University College, Wales.

Larwood, J.G., and Whatley, R.C., 1993. Tertiary to Recent evolution of Ostracoda in isolation on seamounts. In McKenzie, K.G., and Jones, P. (Eds.), Ostracoda in the Earth and Life Sciences: 531-549.

Millson, K.J., 1987. The paleobiology of Paleogene ostracoda from the Deep Sea Drilling Project in the South West Pacific [Ph.D. dissert.]. University College, Wales.

Premoli Silva, I., Haggerty, J., Rack, F., et al., 1993. Proc. ODP, Init. Repts., 144: College Station, TX (Ocean Drilling Program).

Smith, P.D., 1983. Quaternary deep sea ostracoda from the Southwest Pacific [M.S. thesis]. University College, Wales.

Teeter, J.W., 1973. Geographic distribution and dispersal of some recent shallow-water marine Ostracoda. Ohio J. Sci., 73:46-54.

Titterton, R., and Whatley, R.C., 1988. The provincial distribution of shallow water Indo-Pacific marine Ostracoda: origins, antiquity, dispersal routes and mechanisms. In Hanai, T., Ikeya, N., and Ishizaki, K. (Eds.), Evolutionary Biology of Ostracoda: Its Fundamentals and Applications: Amsterdam (Elsevier), 759-786.

Whatley, R.C.. 1987. The southern end of Tethys: an important locus for the origin and evolution of both deep and shallow water Ostracoda. In McKenzie, K.G. (Ed.), Shallow Tethys 2: Rotterdam (A.A. Balkema), 461-474.

Whatley, R.C., and Ayress, M.A.., 1988. Pandemic and endemic distribution patterns in Quaternary deep-sea Ostracoda. In Hanai, T., Ikeya, N., and Ishizaki, K. (Eds.), Evolutionary Biology of Ostracoda: Its Fundamentals and Applications: Amsterdam (Elsevier), 739-755.

Whatley, R.C., Downing, S.E., Kesler, K., and Harlow, C.J., 1984. New species of the ostracod genus Bradleya from the Tertiary and Quaternary of D.S.D.P. sites in the Southwest Pacific. Rev. Esp. Micropaleontol., 16:265298.

1986. The ostracode genus Poseidonamicus from the Cainozoic of D.S.D.P. sites in the SW Pacific. Rev. Esp. Micropaleontol., 18:387-400.

Abbreviations for names of organizations and publications in ODP reference lists follow the style given in Chemical Abstracts Service Source Index (published by American Chemical Society).

Date of initial receipt: 31 January 1994

Date of acceptance: 15 June 1994

Ms 144SR-072 


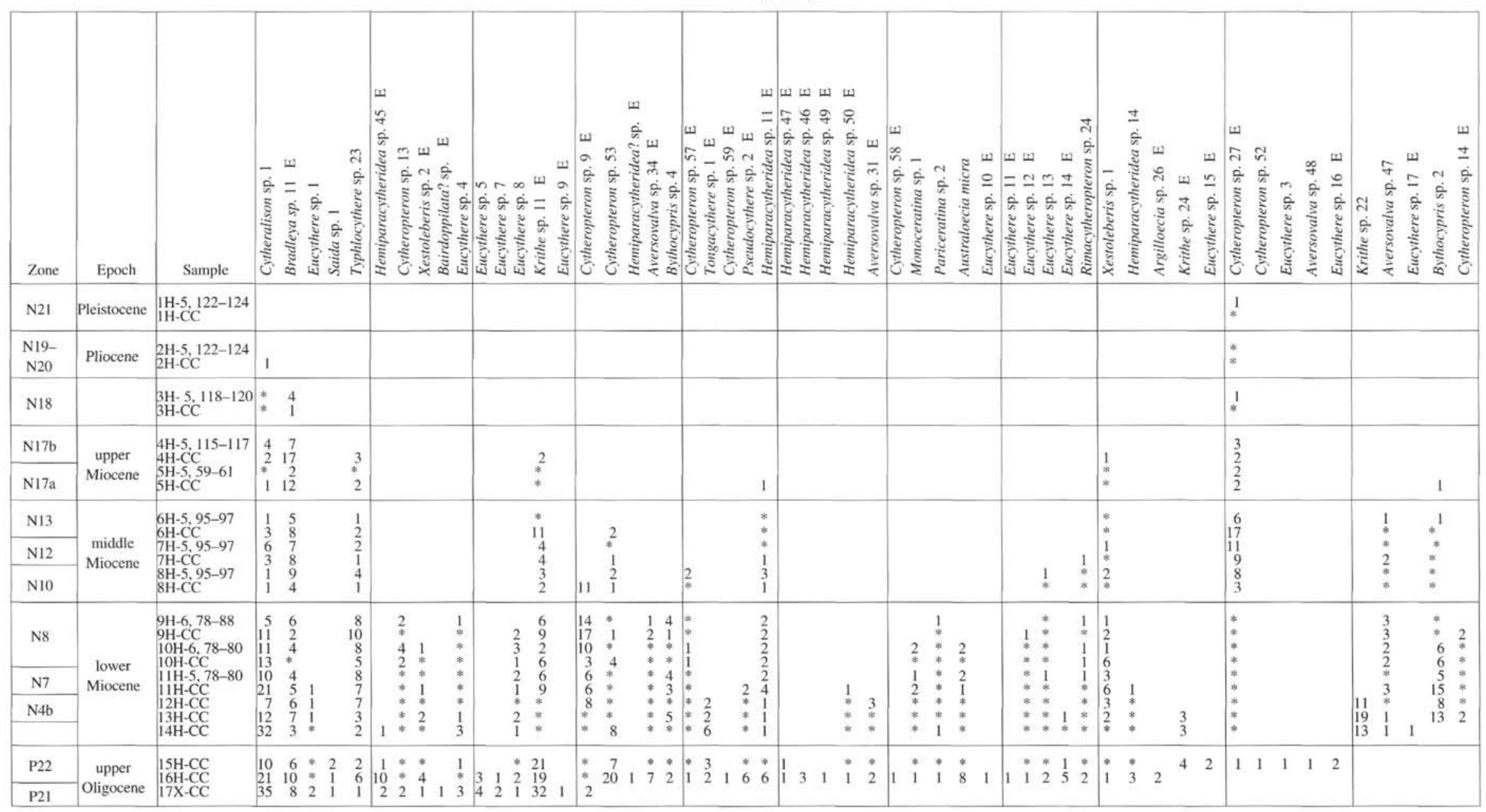

Notes: Foraminifer zones and stratigraphic distribution after Shipboard Scientific Party $(1993 \mathrm{~b})$. Asterisk $(*)=$ Lazarus occurrence. $E=$ taxa considered to be endemic to each site. Plus sign $(+)=$ allochthonous species. 
Table 2 (continued)

\begin{tabular}{|c|c|c|c|c|c|c|c|c|c|c|c|c|}
\hline Zone & Epoch & Sample & 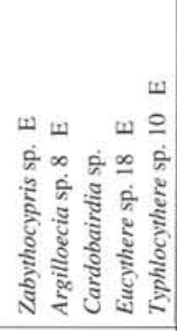 & 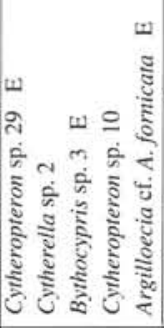 & 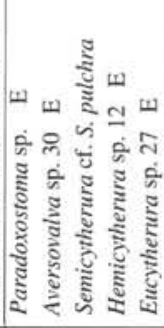 & 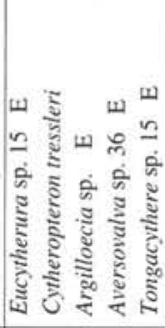 & 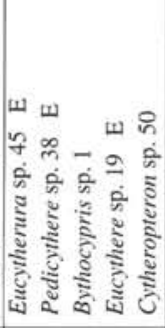 & 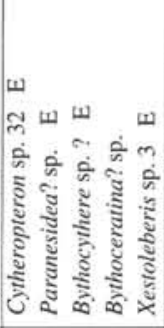 & 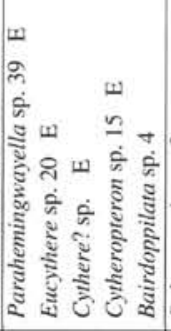 & 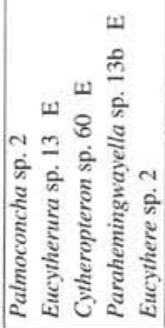 & 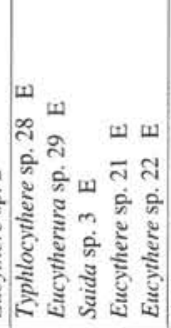 & 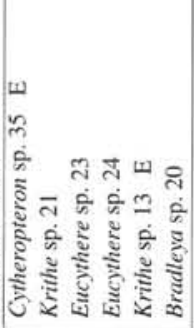 \\
\hline $\mathrm{N} 21$ & Pleistocene & $\begin{array}{l}\text { IH-5, } 122-124 \\
\text { IH-CC }\end{array}$ & & & & & & & & & & $\begin{array}{l}2 \\
* \\
*\end{array}$ \\
\hline $\begin{array}{l}\mathrm{N} 19- \\
\mathrm{N} 20\end{array}$ & Pliocene & $\begin{array}{l}2 \mathrm{H}-5,122-124 \\
2 \mathrm{H}-\mathrm{CC}\end{array}$ & & & & & & & & & & i \\
\hline N18 & & $\begin{array}{l}\begin{array}{l}3 \mathrm{H}-5,118-120 \\
3 \mathrm{H}-\mathrm{CC}\end{array} \\
\end{array}$ & * & & & & & & & & & 1 \\
\hline $\mathrm{N} 17 \mathrm{~b}$ & upper & $\begin{array}{l}4 \mathrm{H}-5,115-117 \\
4 \mathrm{H}-\mathrm{CC}\end{array}$ & 2 & & & $2 \frac{1}{2}$ & & & & & & \\
\hline N17a & Miocene & $\begin{array}{l}5 \mathrm{H}-5,59-61 \\
5 \mathrm{H}-\mathrm{CC}\end{array}$ & $*$ & $1 \stackrel{1}{*}$ & $\begin{array}{l}1 \\
1\end{array}$ & $\begin{array}{ll}* & 1 \\
1 & 2 \\
\end{array}$ & & & & & $1 * *$ & $\begin{array}{ll}2 & 1 \\
5 & \end{array}$ \\
\hline $\mathrm{N} 13$ & \multirow{3}{*}{$\begin{array}{l}\text { middle } \\
\text { Miocene }\end{array}$} & \multirow{3}{*}{$\begin{array}{l}6 \mathrm{H}-5,95-97 \\
6 \mathrm{H}-\mathrm{CC} \\
7 \mathrm{H}-5,95-97 \\
7 \mathrm{H}-\mathrm{CC} \\
8 \mathrm{H}-5,95-97 \\
8 \mathrm{H}-\mathrm{CC}\end{array}$} & \multirow{3}{*}{$\begin{array}{ll}1 & \\
1 & \\
1 & \\
* & \\
2 & 3 \\
* & *\end{array}$} & \multirow{3}{*}{$\begin{array}{lll} & * & * \\
1 & * & * \\
* & * & * \\
* & * & * \\
* & * & * \\
* & * & 2\end{array}$} & \multirow[b]{3}{*}{ * } & \multirow{3}{*}{$\begin{array}{ll}* & 3 \\
* & 1 \\
* & * \\
1 & 1 \\
* & 1 \\
* & 2\end{array}$} & \multirow[b]{3}{*}{ t } & & & \multirow[b]{3}{*}{$11^{1} 1^{1}$} & \multirow{3}{*}{$\begin{array}{llll}* & * & * & \\
* & 1 & 1 & 1 \\
* & 1 & & \end{array}$} & \multirow[t]{3}{*}{11} \\
\hline $\mathrm{N} 12$ & & & & & & & & & & & & \\
\hline N10 & & & & & & & & & & & & \\
\hline N8 & \multirow[t]{2}{*}{$\begin{array}{l}\text { lower } \\
\text { Miocene }\end{array}$} & \multirow{2}{*}{$\begin{array}{l}9 \mathrm{H}-6,78-88 \\
9 \mathrm{H}-\mathrm{CC} \\
10 \mathrm{H}-{ }^{2}, 78-80 \\
10 \mathrm{H}-\mathrm{CC} \\
11 \mathrm{H}-5,78-80 \\
11 \mathrm{H}-\mathrm{CC} \\
12 \mathrm{H}-\mathrm{CC} \\
13 \mathrm{HCC} \\
14 \mathrm{H}-\mathrm{CC}\end{array}$} & \multirow{2}{*}{\begin{tabular}{lll|} 
& $*$ & $*$ \\
& $*$ & $*$ \\
& $*$ & 1 \\
1 & $*$ & $*$ \\
$*$ & $*$ & $*$ \\
$*$ & 1 & 1 \\
1 & 1 & 2
\end{tabular}} & \multirow{2}{*}{$\begin{array}{lllll}3 & * & * & & \\
* & * & * & & \\
: & * & * & 5 & \\
* & * & * & * & \\
1 & * & * & * & \\
2 & * & 4 & 2 & 1 \\
2 & 1 & & & \end{array}$} & \multirow[t]{2}{*}{$\begin{array}{llllll} & * & & & & \\
& * & & & & \\
1 & & & & \\
& * & & & & \\
1 & 1 & & 1 & 1 & 1\end{array}$} & \multirow[t]{2}{*}{$\begin{array}{lllll}1 & 1 & & * & 2 \\
* & 1 & & * & 4 \\
* & * & 1 & * & 1 \\
* & * & * & * & 4 \\
* & * & 2 & 1 & 1 \\
1 & 1 & & & \end{array}$} & \multirow[t]{2}{*}{ 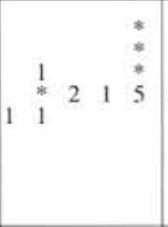 } & \multirow[t]{2}{*}{ 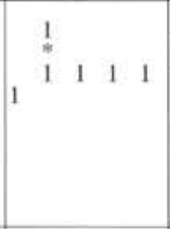 } & \multirow[t]{2}{*}{$\mid$\begin{tabular}{lllll|l}
1 & 1 & 1 & 1 & 1
\end{tabular}} & & & \\
\hline $\mathrm{N} 4 \mathrm{~b}$ & & & & & & & & & & & & \\
\hline $\mathrm{P} 22$ & \multirow{2}{*}{$\begin{array}{c}\text { upper } \\
\text { Oligocene }\end{array}$} & \multirow{2}{*}{$\begin{array}{l}15 \mathrm{H}-\mathrm{CC} \\
16 \mathrm{HCC} \\
17 \mathrm{X}-\mathrm{CC}\end{array}$} & & & & & & & & & & \\
\hline $\mathrm{P} 21$ & & & & & & & & & & & & \\
\hline
\end{tabular}


Table 3. Ostracod biostratigraphy of Hole 873B.

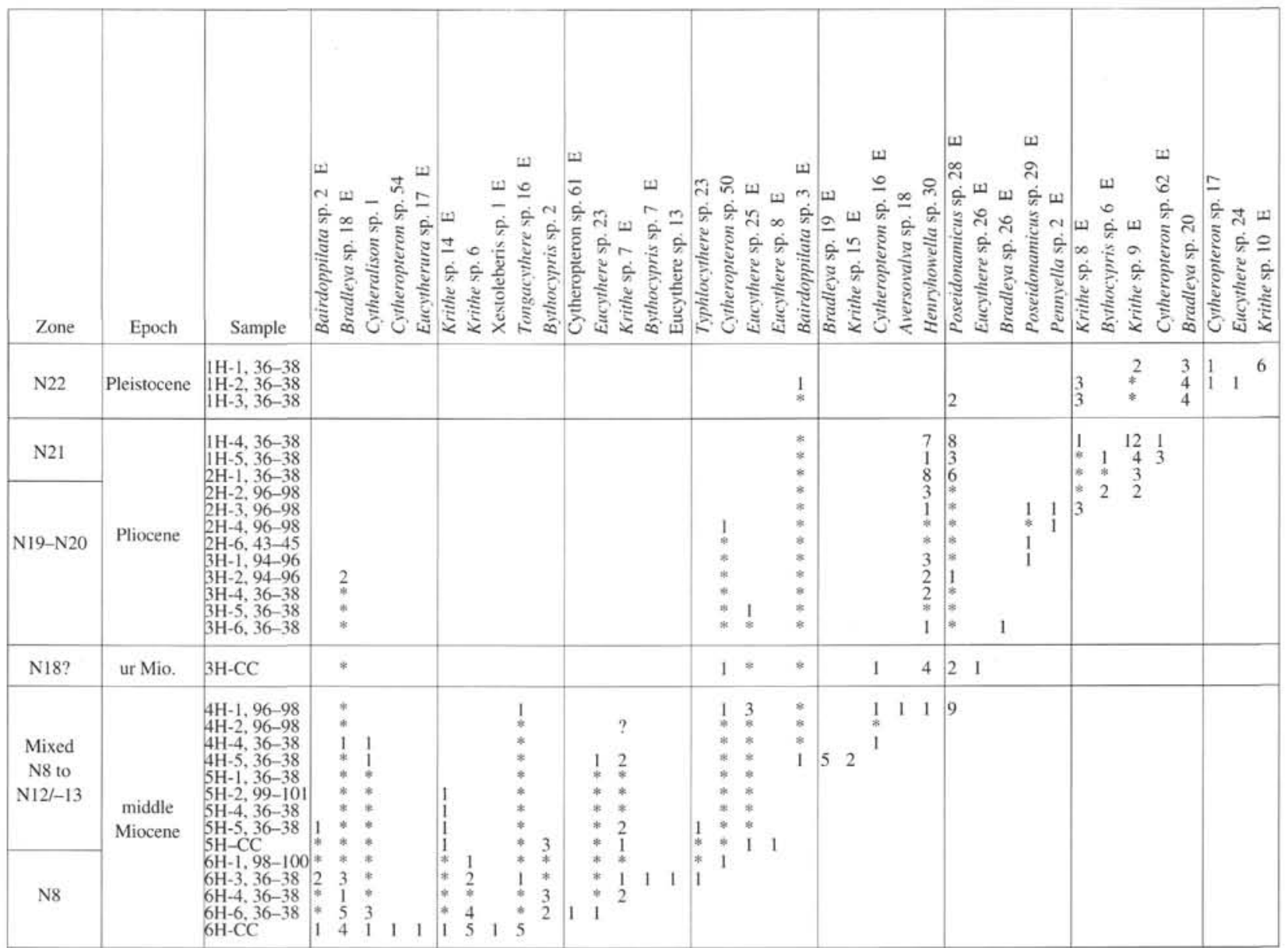

Notes: Foraminifer zones and stratigraphical distribution after Shipboard Scientific Party (1993c). Asterisk $(*)=$ Lazaraus occurrence. E $=$ taxa considered to be endemic to each site. 


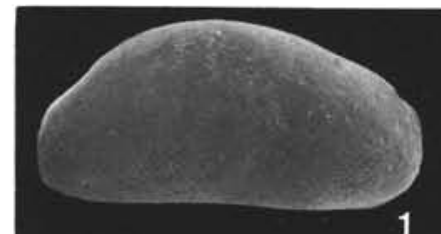

1

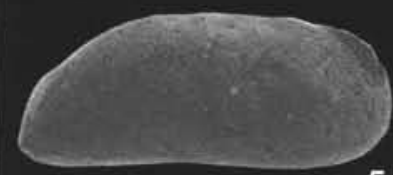

5

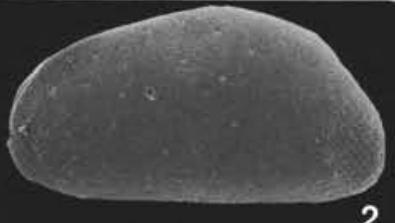

2

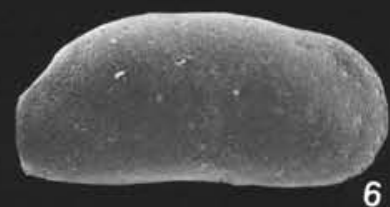

6

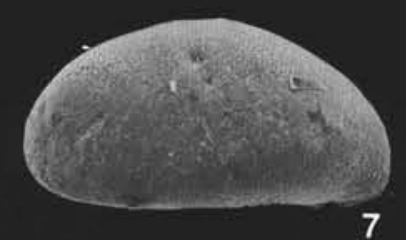

7
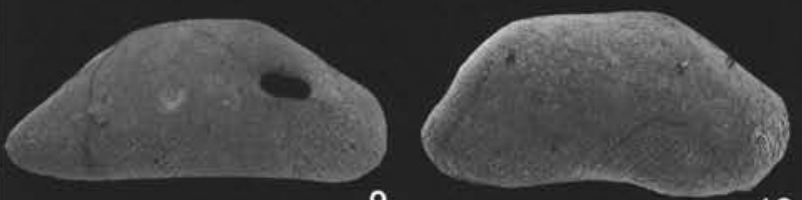

10

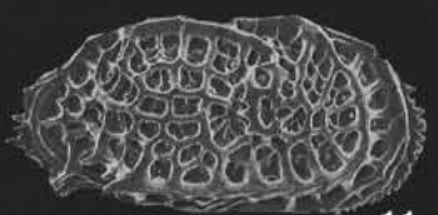

11

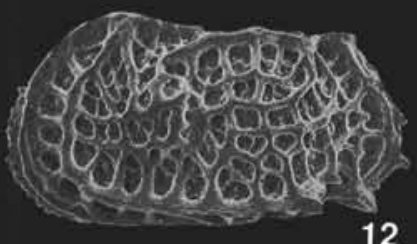

12

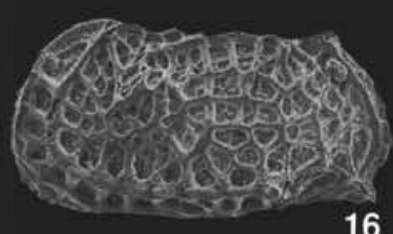

14

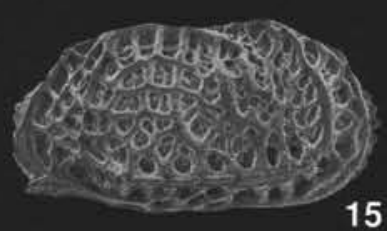

16
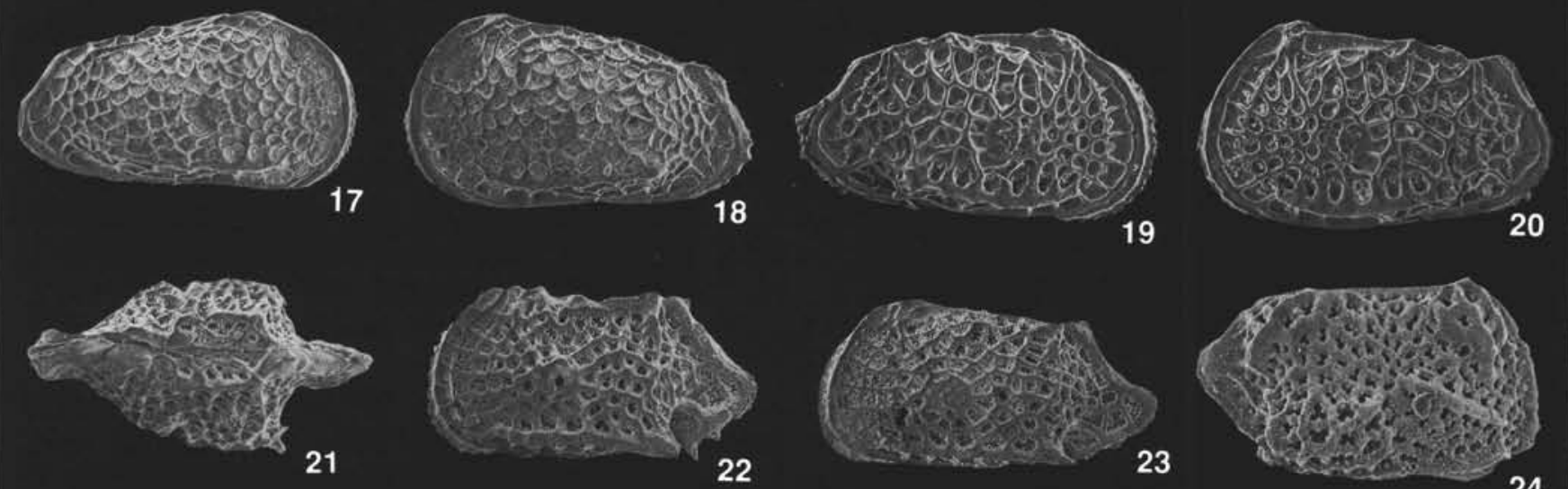

19

20

Plate 1. 1-2. Krithe sp. 11, Sample 144-872C-11H-CC, 50x; (1) RV; (2) LV. 3, 5. Krithe sp. 8, Sample 144-873B-1H-4, 36-38 cm; (3) RV female, 51×; (5) RV male 43x. 4, 6. Krithe sp. 9, Sample 144-873B-2H-2, 96-98 cm, 50x; (4) LV; (6) RV. 7-8. Xestoleberis sp. 1, Sample 144-872C-11H-CC, 107×; (7) RV; (8) LV. 9. Bythocypris sp. 2, Sample 144-872C-11H-CC; RV, 34×. 10. Bythocypris sp. 4, Sample 144-872C-11H-5, 78-80 cm; RV, Juv. A-1, 53×. 11-12. Bradleya sp. 18, Sample 144-873B-6H-6, 36-38 cm, 4Ix; (11) RV; (12) LV. 13-14. Bradleya sp. 20; (13) RV, Sample 144-873B-1H-2, 36-38 cm, 35×; (14) LV, Sample 144-873B-1H-1, 36-38 cm, 35×. 15-16. Bradleya sp. 11; (15) RV, Sample 144-872C-7H-CC, 40x; (16) LV, Sample 144-872C-11H-5, 78-80 cm. 40×. 17-18. Poseidonamicus sp. 29, Sample 144-873B-1H-5, 36-38 cm, 42×; (17) RV; (18) LV. 19-20. Poseidonamicus sp. 28, Sample 144-873B-4H-1, 96-98 cm, 41×; (19) RV; (20) LV. 21-22. Tongacythere sp. 16, Sample 144-873B-6H-CC, 45x; (21) carapace, dorsal view; (22) LV. 23. Tongacythere sp. 15, Sample 144-872C-4H-CC, LV, 40x. 24. Eucytherura sp. 27, Sample 144-872C-11H-CC, RV, 124x. RV = right valve, and LV=left valve. 

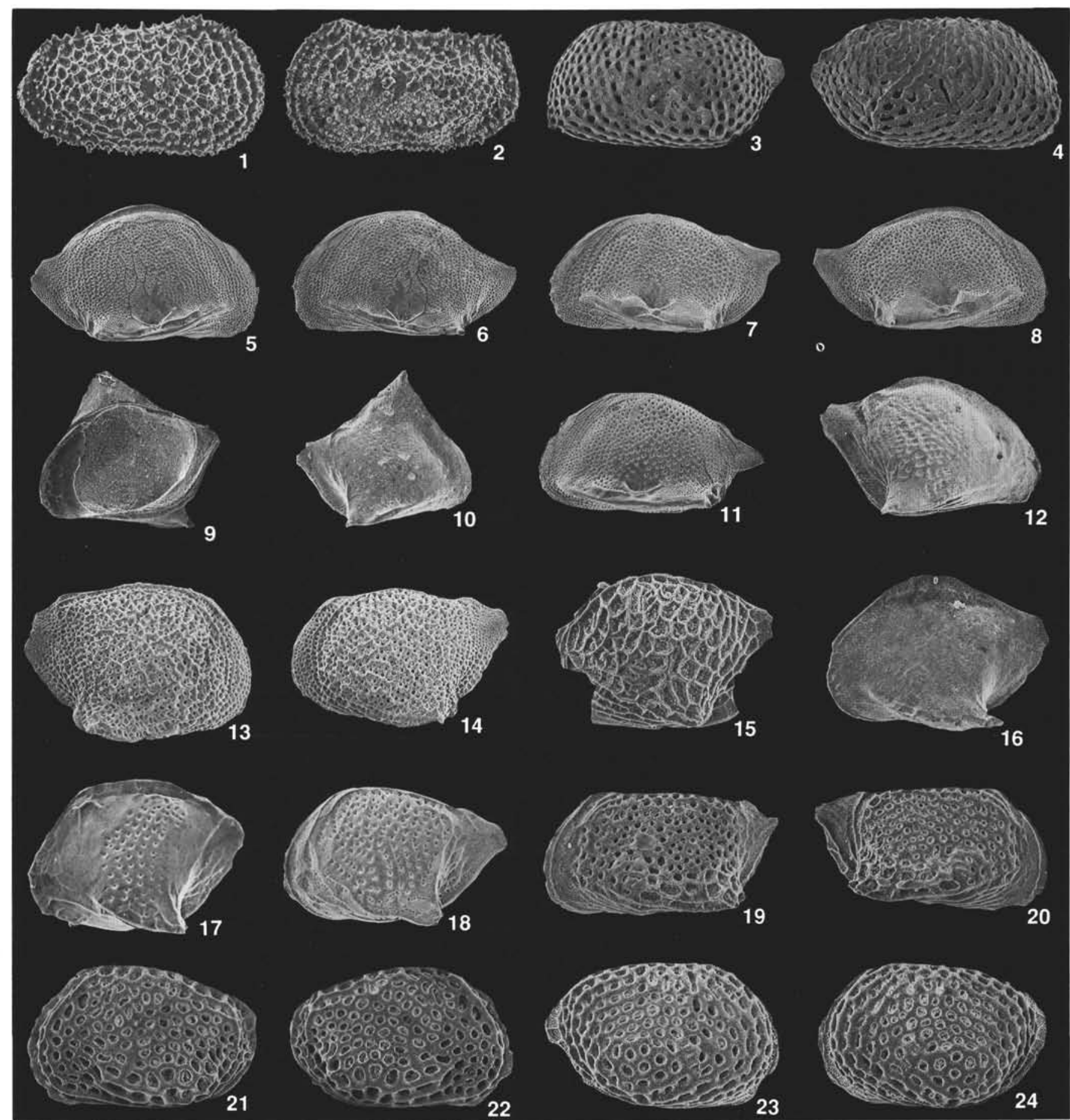

Plate 2. 1-2. Henryhowella sp. 30; (1) Sample 144-873B-2H-2, 96-98 cm, RV, 51×; (2) Sample 144-873B-3H-2, 94-96 cm, LV, 48×. 3-4. Cytheralison sp. 1; (3) Sample 144-872C-11H-CC, LV, 38x; (4) Sample 144-873B-6H-6, 36-38 cm, RV, 42×. 5-6. Cytheropteron sp. 37, Sample 144-872C-5H-5, 59-61 cm, 49×; (5) RV; (6) LV. 7-8. Cytheropteron sp. 9, Sample 144-872C-11H-CC, 54x; (7) LV; (8) RV. 9-10. Cytheropteron sp. 32, Sample 144-872C-10H-CC; (9) RV internal, 49×; (10) RV external, 51×. 11. Cytheropteron sp. 17, Sample 144-873B-1H-1, 36-38 cm, LV, 37×. 12. Cytheropteron sp. 13, Sample 144-872C-10H-CC, RV, 50×. 13-14. Cytheropteron sp. 14, Sample 144-872C-9H-CC; (13) RV, 88×; (14) LV 79x. 15. Cytheropteron sp. 29, Sample 144-872C-11H-CC, LV, broken, 92×. 16. Aversovalva sp. 34, Sample 144-872C-9H-CC, LV, Juv. A-1, 92×. 17. Aversovalva sp. 36, Sample 144-872C-5HCC, LV, 92×. 18. Cytheropteron sp. 10, Sample 144-872C-11H-CC, LV, 82×. 19-20. Hemiparacytheridea sp. 11; (19) Sample 144-872C-8H-5, 95-97 cm, LV, 109x; (20) Sample 144-872C-8H-CC, RV, 112x. 21-22. Typhlocythere sp. 10, Sample 144-872C-8H-5, 95-97 cm, 122×; (21) LV; (22) RV. 23-24. Typhlocythere sp. 23, Sample 144-872C-8H-5, 95-97 cm, 116x; (23) RV; (24) LV. RV = right valve, and LV = left valve. 